\title{
Confidence Index Determinants of the Amman Stock Exchange Listed Companies
}

\author{
Imad Zeyad Ramadan ${ }^{1}$ \\ ${ }^{1}$ Department of Finance, Applied Science University, Amman, Jordan \\ Correspondence: Imad Zeyad Ramadan, Associate Prof., Department of Finance, Applied Science University, \\ P.O. Box 166, Amman, Jordan. E-mail: i_ramadan@asu.edu.jo
}

Received: October 14, 2014

Accepted: November 12, 2014

Online Published: December 20, 2014

doi:10.5539/ijbm.v10n1p195

URL: http://dx.doi.org/10.5539/ijbm.v10n1p195

\begin{abstract}
Price/Earnings (P/E) ratio, a well known assessment method, has constantly remained at the centre of awareness of market analysts and investors ever since the origin of discounted dividend growth model of Gordon and Shapiro (1956). In line with that, this study aims to reveal the variables that explain the variation in P/E ratio, a proxy of the confidence index, by using unbalanced pooled cross-sectional time series Ordinary Least Square (OLS) regression model on Amman Stock Exchange listed companies for the period 1999-2013. Financial sector firms' and non-consistently dividends-paying firms were excluded resulting in 1380 firm-year observation. Results implied that dividend payout ratio, earning growth rate, Tobin's Q and firm size significantly clarify variations in confidence index of firms listed in ASE, demonstrating that investors' confidence of investing in ASE is more for small company with higher dividend payout ratio, high earning growth rate and high firm's market value. This paper is likely to help decision makers to assess variables that can clarify contrast in company's P/E ratio in order to gain investors' confidence and thus choose these companies to be a part of their portfolio.
\end{abstract}

Keywords: confidence index, price-earnings ratio, Amman Stock Exchange

\section{Introduction}

It is well known that there are many factors that play a role in determining the prices of shares traded in the financial markets, It is also known that some of these factors may not be quantitative or financial factors. For financial analysts the identification of these factors is the most important everyday's problems they face. Proceeding from this problem, this study seeks to identify factors that affect the $\mathrm{P} / \mathrm{E}$ ratio, a proxy of the confidence index, of companies listed in the Amman Stock Exchange (ASE). P/E ratio, a proxy of the confidence index, is a kind of cash flow variation model, and thus varies from one company to another depending on the macro and firm-specific accounting variables.

The association between share prices and basics (e.g. firm income, dividends and book-value) has always remained as the focus area of attention. In this view, $\mathrm{P} / \mathrm{E}$ ratio has gained huge reputation for assessing individual stocks, sectors and stock markets as possible investments. .Existing literature has sorted the determinants of P/E ratio in accordance with to the market analysis and sector analysis.

Several studies conducted on the determinants of the P/E ratio using different samples in developing and developed markets have reached different results with respect to the determinants of this ratio. White (2000), concluded that dividend payout, dividend yield, earnings growth, GDP growth, Inflation, Federal P/E index, market return, standard deviation of returns, and T-bill rates are the main determinants of the price-earnings ratio, while the dividend payout and dividend yield have the most important influence among other factors on the price-earnings ratio. By using the standard \& poor 500 index for the period 1953 to 2003, Dudney et el. (2008) examined the effect of fundamental factors on E/P ratio and concluded that short term interest rate, default risk premium, tax rates, inflation and expected growth have a statistically significant effect on the E/P ratios.

Anderson and Brooks (2006) concluded that the price-earnings ratio for UK firms are significantly affected with firm's size, the year in which $\mathrm{P} / \mathrm{E}$ is considered and the industry consequence.

Shamsudin and Hiller (2004) exams the determinants of the P/E ratio for the Australian market using the ASE 200 Index. The results concluded that price-earnings ratio affected significantly positively by dividend payout 
ratio, appreciation of the Australian currency, increase in GDP, and an improvement in consumer's confidence, and significantly negatively by interest rates and market volatility. Gill (2003) concluded a positively association between earnings and piece-earnings ratio for the Indian capital market. While Kumar and Warne (2009) concluded that variability in market price and corporate size are the significant determinants of price-earnings ratio for the same capital market.

The importance of this study stems from being the first study, according to the knowledge of the researcher, which seeks to test the factors that affect the confidence index in companies listed in ASE. Just about all investors know that the macro and firm-specific accounting variables regularly have a enormous force on companies performance and then it affects the future earnings and stock prices. As a result, it is of big interest to aim to clarify how a change in these variables affects the $\mathrm{P} / \mathrm{E}$ ratio.

The conflict of thoughts about the $\mathrm{P} / \mathrm{E}$ ratio, proxy of the confidence index, is the core of a great deal of attention, and still a point of contention among financial researchers worldwide, therefore, the key question that the paper seeks to answer is: is there any significant impact of dividend payout ratio, earning growth rate, discount rate, leverage, profitability and size of the companies listed in Amman Stock Exchange on their share price? For that reason, the paper seeks to test the following hypothesis:

$H_{0}$ : There is no significant effect of the dividend policy, earning growth rate, discount rate, leverage, profitability and firm's size on their share price for the Amman Stock Exchange listed companies.

Thus, the null hypothesis can be formed as:

$$
\mathrm{H}_{0}: \beta_{\mathrm{i}}=0, \quad|\operatorname{sig}<0.05|
$$

Where: $H_{0}$ is the null hypothesis to be tested; $\beta_{i}$ is the regression coefficient of the independent variables in the econometric model to be estimated.

As on Baskin, (1989) the multiple OLS method has been utilized to accomplish the goals of the study and test its hypotheses. The explanatory variables i.e., dividend payout ratio, earnings growth rate and discount rate have been used to explain the firm's price variation while controlling for firm's leverage ratio, Tobin's $Q$ and size.

\section{Research Methodology}

\subsection{Data collection and Methodology}

This paper adopts the quantitative research approach by using unbalanced pooled cross-sectional time series OLS regression model for all Amman Stock Exchange Listed Companies within the time period 1999-2013. Financial sector firms and non-consistently dividends-paying firms to their share holders were excluded resulting in 1380 firm-year observation for the complete time period. Needed financial information, namely P/E ratio, dividend payout ratio, earnings growth rate, discount rate, firm's size, leverage ratio and Tobin's Q, has been driven from the historical information provided by officially website of the Amman Stock Exchange (ASE).

Confidence index will be expressed in this study through the price to earnings ratio (P/E ratio). The P/E ratio is an assessment ratio of a company's current price per share compared to its earnings per share. It is also at times identified as "earnings multiple" or "price multiple". Even though Price-earnings ratio has some shortcoming but it is at rest the most suitable method to assess prospective investments, and thus, give an indication about the extent of investor confidence in the future investments.

The Confidence index model, expressed as the $\mathrm{P} / \mathrm{E}$ ratio, has been driven in this study from the origin Gordon and Shapiro (1956) discounted dividend growth model. There are three explanatory variables in this model specifically; dividend payout ratio (DPR), earnings growth rate (EGR) and discount rate (DR) as considered explaining the variation in the confidence index, for all the dividend-paying manufacturing firms listed at ASE over a period from 1991 to 2014. This model stated that the current share price $\mathrm{p}_{0}$ is the present value of a long series of future expected dividends, where $\mathrm{D}_{1}$ is the coming period dividend. The dividend is estimated to grow at a stable rate of $\mathrm{g}$ in this model, and all investors have a wanted return on their stock investment equal to $\mathrm{r}$, which must to be greater than $\mathrm{g}$. Accordingly, the model can be rewritten as follows:

$$
p_{0}=\frac{D_{1}}{r-g}
$$

The model stated that the current stock price is a function of dividends discounted with the difference between the wanted return and its expected growth.

To derive the confidence index, expressed by $\mathrm{P} / \mathrm{E}$ ratio, we can divided both sides of the equation with the expected earnings per share, $E_{1}$, resulting in: 


$$
\begin{gathered}
p_{0}=\frac{D_{1}}{r-g}=\frac{E_{1}(1-s)}{r-g}, \text { thus } \\
\frac{\mathrm{p}_{0}}{\mathrm{E}_{1}}=\frac{(1-\mathrm{s})}{\mathrm{r}-\mathrm{g}}
\end{gathered}
$$

Where

$\mathrm{p}_{0}$ :Current price, $\mathrm{D}_{1}$ : The coming period dividend, $\mathrm{E}_{1}$ : The coming year earnings per share, $\mathrm{r}$ : Discount rate (wanted return), g: Earnings growth rate, $(1-\mathrm{s})$ ): Payout ratio.

From the equation (3) we can spot straightforwardly what variable that drives and affect the confidence index. Thus, by rewriting the third equation, we can observe that the confidence index follows from a function as:

$$
\begin{gathered}
\frac{p_{0}}{E_{1}}=f(\text { Dividend payout ratio, Earnings growth rate, Discount rate }) \\
{\left[\frac{p}{E}\right]_{i t}=\alpha_{i}+\beta_{1}(\text { Div. Payout })_{i t}+\beta_{2}(\text { E.growth })_{i t}+\beta_{3}(\text { Disc.rate })_{i t}+U_{i}+\varepsilon_{i t}}
\end{gathered}
$$

and thus,

$$
Y_{i t}=\alpha_{i}+\beta_{1} D P R_{i t}+\beta_{2} E G R_{i t}+\beta_{3} D R_{i t}+\mathcal{U}_{i}+\varepsilon_{i t}
$$

Where

$Y_{i t}=\left[\frac{p}{E}\right]_{i t}:$ Confidence index for the $\mathrm{i}^{\text {th }}$ firm for the $\mathrm{t}^{\text {th }}$ time, as $i=1,2,3, \ldots i, t=1,2,3, \ldots, 15, \alpha$ : is constant, $\beta$ 's unknown parameters of the firm's $P / E$ ratio as a proxy of its confidence index which includes $D P R, E G R$, and $D R$ to be estimated; $\alpha$ : is constant $D P R$ : Dividend payout ratio, EGR: Earnings growth rate, DR : Discount rate, $\mathcal{U}:$ All other variables that affect the variable $Y$ and $\varepsilon$ : The random error.

\subsection{Econometric model}

The variables explaining variations in the confidence index, expressed as the P/E ratio, of the Amman Stock Exchange Listed Companies, taking into account the instability in ASE throughout the study period, are appraised by utilizing OLS regression on unbalanced pooled cross-sectional time series data for the period 19992013.

As for the statistical test, the price/earnings ratio (P/E) as proxy of the confidence index was chosen to be the dependent variable in the econometric model of the study, while factors affecting the share price as well as the special characteristics of the firm were selected as the independent variable in the econometric model of study.

The confidence index can be viewed as a function of dividend payout ratio, earning growth rate and discount rate. And the general model representing this multiple regression can be estimated as shown in Equation 5.

Because the Tobin's Q, leverage, and the size of the firm may affect dividend payout ratio, earnings growth rate, discount rate and/or current price, three control variables i.e., firm's size, leverage and Tobin's $Q$ are added, and Eq. 5 can be rewritten as follows:

$$
Y_{i t}=\alpha_{i}+\beta_{1} D P R_{i t}+\beta_{2} E G R_{i t}+\beta_{3} D R_{i t}+\gamma_{4} S I Z_{i t}+\gamma_{5} L E V_{i t}+\gamma_{6} Q_{i t}+u_{i}+\varepsilon_{i t}
$$

Where

$\mathrm{Y}_{\mathrm{it}}=\left[\frac{\mathrm{p}}{\mathrm{E}}\right]_{\mathrm{it}}:$ Confidence index $\mathrm{i}^{\text {th }}$ firm for the $\mathrm{t}^{\text {th }}$ time, as $i=1,2,3, \ldots, i, t=1,2,3, \ldots, 15, \alpha$ : is constant, $\beta^{\text {'s }}$ unknown parameters of the firm's P/E ratio as a proxy of its confidence index which includes DPR, EGR, and DR to be estimated; $\gamma$ unknown parameters be estimated, DPR: Dividend payout ratio, EGR: Earnings growth rate, DR: Discount rate, $\mathcal{U}$ :Allothervariablesthat affectthevariable $\mathrm{Y}$ and $\varepsilon$ : The random error.

\subsection{Variables Measurement}

\subsubsection{Dependent Variable}

The $\mathrm{P} / \mathrm{E}$ ratio is basically the stock price divided by the earnings-per-share (EPS). Usually, when $\mathrm{P} / \mathrm{E}$ ratio is calculated using the past year reported earnings, it known as the trailing $\mathrm{P} / \mathrm{E}$ ratio, while when using the 
estimated earnings for the next year to calculate the ratio, we refer it as the forward $\mathrm{P} / \mathrm{E}$ ratio.

By connecting share prices to profits, the $\mathrm{P} / \mathrm{E}$ ratio highlights the association between the price and firm's performance. If prices and earnings move up, the ratio stays with no changes. The ratio only change as price and profits movements are different in the percentage amount and/or direction. For this reason, when the ratio is different than normal, this indicates that the current profit levels are no longer the major issue in pricing the stock. This might be because change is going on - investors expect a much better or worse performance next year - or because emotion is at this time the main issue.

With other variables held constant, the firms that have a high P/E ratio indicate that the investors are willing to pay more amount of money for the one dollar of the firm's profits comparing to firm's that have a low P/E ratio. This willingness to pay a larger amount of money for the same dollar profits resulting from the fact that the investors expects a better future for the firm with the higher P/E ratio than the firm with the lower P/E ratio, prompting investors to pay a higher price for the same dollar profit. From the above we can understand the reason for looking at the $\mathrm{P} / \mathrm{E}$ ratio as an indicator of the investors' confidence in the firm.

Price-earnings ratio (P/E) as a proxy of the confidence index can simply computed as the ratio of the current price (yearly closing price) to its earnings per share as shows:

$$
P_{i t} E_{i t}=\frac{(\text { current price per share })_{i t}}{(\text { earnings per share })_{i t}}
$$

Where

$P_{i t} / E_{i t}$ : Price-earnings ratio as a proxy of the confidence index, $\mathrm{i}^{\text {th }}$ firm for the $t^{\text {th }}$ time, as $i=1,2,3, \ldots, i, t=$

$$
1,2,3, \ldots, 15 \text {. }
$$

\subsubsection{Independent Variables}

\subsubsection{Dividend Payout Ratio}

The dividend payout ratio (DPR) is one of the six expected explanatory variables i.e., dividend payout ratio, earnings growth rate, discount rate, firm's size, leverage ratio and Tobin's Q in this study. Miller and Modigliani (1961) suggested that if dividend policy does not affect the investment decisions, and assuming a perfect market case, were there is no taxes and transaction costs, the firm's dividend policy should not affect the value of its shares. Thus M\&M 1961sugested no effect for the dividend payout ratio on the confidence index expressed by $\mathrm{P} / \mathrm{E}$ ratio. In other words, if the firm could raise its share price by escalating (or declining) its dividend payout ratio, then all firms would do so, which would saturate the demand for higher (or lower) dividend yields, and would bring about an balance in which changes in a firm's dividend policy would have no impact on the price.

This result of M\&M 1961 implies that as the firms increase or decrees their dividend payout ratio, the P/E will not be affected. This result is consistent with the view that each investor can create a dividend policy consistent with his desires through selling some of his shares whose prices rose as a result of the retained earnings.

The DPRcan be computed as follows:

$$
\mathrm{DPR}_{\mathrm{it}}=\frac{\mathrm{TCD}_{\mathrm{it}}}{\mathrm{NI}_{\mathrm{it}}}
$$

Where:

DPR is the dividend payout ratio, $\mathrm{i}^{\text {th }}$ firm for the $\mathrm{t}^{\text {th }}$ time, as $\mathrm{i}=1,2,3, \ldots, \mathrm{i}, \mathrm{t}=1,2,3, \ldots, 15$, TCD: the total cash dividend for common stock holders, NI: the net income after tax available for common stock holders.

\subsubsection{Earnings Growth Rate}

The earnings growth rate (EGR) is the second expected explanatory variable in this study. William and Morse, (1978), find that when alliance stocks into portfolios basis on their $\mathrm{P} / \mathrm{E}$ ratios, the initial $\mathrm{P} / \mathrm{E}$ differences between the portfolios continue up to 14 years, and earnings growth helps to explain little of the persisting in theP/E differences. However, price-earnings ratios correlate negatively with EGR in the year of the portfolio's formation, and positively with EGR in the following year, signifying that investors are predicting only short-term profit deformities. William and Morse conclude that the most important explanation of the obvious persistence in price-earnings ratios is not EGR, but differences in accounting method.

Earnings growth rate can be computed annually for the purpose of this study as the percentage change in the 
annual earnings per share as follows:

$$
\mathrm{EGR}_{\mathrm{it}}=\frac{\mathrm{EPS}_{\mathrm{it}}}{\mathrm{EPS}_{\mathrm{it}-1}} * 100
$$

Where;

EGR is the earnings growth rate, $i^{\text {th }}$ firm for the $t^{\text {th }}$ time, as $i=1,2,3, \ldots, i, t=1,2,3, \ldots, 15$, EPS: the earnings per share.

\subsubsection{Discount Rate}

Most companies finance capital through borrowing. A lessening in interest rates will drop down the costs of financing and thus, leading to motivate and encourage the firms to expand. If so, a positive impact on future expected returns for the firms is expected. But, as large amount of stocks are transferred with on loan money, an increase in interest rates would make stock dealings more costly and has negative effect on return rate. This case will reduce the demand of the stocks and guide to a price reduction.

Andrew Ang and Xiaoyan Zhang, (2011), computed the P/E ratio using the S\&P500 index and concluded that discount rates (DR) display great variation $27.5 \%$ of the variation in total returns, and are due to persistent of the time-varying expected return components. Nevertheless, while the variation of DR is big, most of the variation of $\mathrm{P} / \mathrm{E}$ ratios reflects growth components. Non-growth components account for $20.7 \%$ of the level of the P/E ratio and the remainder, $79.3 \%$, is due to growth components.

As for the purpose of this study, the discount rate (DR), as an expected explanatory variable of the confidence index, will by expressed as the interest rate at which the central bank of Jordan lends money to other banks in times of need on the money market.

\subsubsection{Firm's Size}

Anderson and Brooks (2006) suggested that the P/E ratios are affected by the firm's size. Cho (1994) find that firm's size had a reveres relationship with E/P ratio.

Previous studies used many proxies for firm's size, such as total assets and sales revenue, Following Cynthia A. (2012), the natural logarithm of total asset has been utilized as a proxy of the firm's size (SIZE), SIZE can be computed as follows:

$$
S I Z E_{i t}=\ln (\text { Total assets })_{i t}
$$

Where;

SIZE is the firm's size, $i^{\text {th }}$ firm for the $t^{\text {th }}$ time, as $i=1,2,3, \ldots, i, t=1,2,3, \ldots, 15, \ln$ : the natural logarithm.

Leverage: Cheng and Zuwei (2011) investigated the effect of leverage on the firm's value. They concluded that when ignoring the bankruptcy cost, the leverage positively affect the value of the firms, as firms with high debt in the capital structure tend to be higher-value of firms with less debt. They also concluded that when taking the benefits and costs of borrowing into account at the same time, the effect of leverage on the firm's value is positive, in a way that it increases its value, as long as the firm did not reach its optimal capital structure. Another finding is that the positive effect of leverage on the value of the firm is stronger when the financial solvency and quality of the firm is better. This result is consistent with the view that using leverage can leads to maximizing the value of the firm.

According to Ward and Price (2006), financial leverage is the percentage of the capital which is financed by debt against equity. Firer et. al. (2004) indicates that the capital structure is the amounts of debt and equity a firm uses to finance its ongoing activities. Thus, leverage ratio is a financial phrase used to explain the way that a firm finances its assets. Particularly, it shows the amount of equity a firm has in relative to its debt; therefore it meant to assess a firm's debt levels. The most common leverage ratios are the debt ratio and the debt-to-equity ratio. For the purpose of this study, the debt ratio has used a proxy of the leverage ratio, and can be computed as the ratio of the total debt to the total assets as follows:

$$
\mathrm{LEV}_{\text {it }}=\frac{(\text { Total Debt })_{\text {it }}}{(\text { Total Assets })_{\text {it }}}
$$

Where;

LEV is the leverage ratio expressed as the debt ratio,$i^{\text {th }}$ firm for the $t^{\text {th }}$ time, as $i=1,2,3, \ldots, i, t=1,2,3, \ldots, 15$. 


\subsubsection{Tobin's Q}

A financial ratio named after the economic Nobel Prize winner in economics from Yale University, James Tobin, who assumed that the total market value of all firms on the stock market must be equal to their substitute costs. The Tobin's Q Ratio (Q ) ratio is calculated as the ratio of the firm's market value to the replacement cost of the firm's assets as follows:

$$
Q_{\text {it }}=\frac{\mathrm{MV}_{\text {it }}}{(\text { replacement cost of the firm's assets })_{\text {it }}}
$$

Where;

$\mathrm{Q}$ is the Tobin's $\mathrm{Q}$ ratio, $\mathrm{i}^{\text {th }}$ firm for the $\mathrm{t}^{\text {th }}$ time, as $\mathrm{i}=1,2,3, \ldots, \mathrm{i}, \mathrm{t}=1,2,3, \ldots, 15, \mathrm{MV}$ : is the market value of the firm.

While a low Q indicate that the firm stock is undervalued, as the cost of the replacement of the firm's assets are greater than the market value of the firm's stock, a high Q indicate that the firm stock is overvalued, as the market value of the firm's stock is greater than the cost of the replacement of the firm's assets.

\section{Data Analysis and the Empirical Results}

\subsection{Descriptive Analysis}

Table 1 shows the descriptive analysis for all variables included in the study during the fifteen years of the study period, based on data of 1380 firm-year observation for the Amman Stock Exchange Listed Companies, the investors, on average, are ready to pay JD 6.88 as a price for the JD 1.0 of the firm's profit, this indicate that in general investors have confidence for investing in Amman Stock Exchange Listed Companies.Also, the table shows an average of $55 \%$ as a dividend payout ratio, $25.6 \%$ for the earnings growth rate and $7.84 \%$ for the discount rate. Leverage, an average of $74.216 \%$, pointed out a heavily use of debt in the capital structure as almost $75 \%$ of the needed money came from borrowing sources, Tobin's Q also verifies high volatility of the firm's stocks values, as the market value to the book value reported an average of 1.362 with a standard deviation of $4.127 \%$.

Table 1. Descriptive analysis

\begin{tabular}{llllll}
\hline Variables & $\mathrm{N}$ & Mean & S.D & Max. & Min. \\
\hline P/E & 1380 & 6.883 & 5.282 & 56.493 & 0.912 \\
DPR & 1380 & 54.986 & 34.396 & 95.2637 & 0 \\
EGR & 1380 & 25.6331 & 83.489 & 654.452 & -70.958 \\
DR & 1380 & 7.840 & 0.978 & 9.75 & 6.75 \\
Q & 1380 & 1.362 & 4.127 & 2.470 & 1.134 \\
LEV \% & 1380 & 74.216 & 57.945 & 92.452 & 2.6155 \\
SIZE & 1380 & 4.556 & 0.810 & 5.513 & 3.744 \\
\hline
\end{tabular}

Note. Where $\mathrm{P} / \mathrm{E}$ is the price earnings ratio as a proxy of the confidence index; DPR is the dividend payout ratio, EGR is the earnings growth ratio; DR is the discount rate; Q is the Tobin's Q; LEV is the leverage ratio expressed as the dept ratio; SIZE is the firm's size which is the natural logarithm of total asset.

\subsection{Correlation Analysis}

Table 2 shows the correlation coefficients between the variables during the study period. As the correlation coefficients with statistical significance between the variables of the study was less than 0.398 , table 2 shows there is no multicollinearity problem in the data. Table 2 also shows that the confidence index of firms is positively related with firm's EGR, while, negatively related with DR, LEV and SIZE. This result fits in perfectly with the expected relationships. 
Table 2. Variables correlation matrix

\begin{tabular}{|c|c|c|c|c|c|c|c|}
\hline & $\mathrm{P} / \mathrm{E}$ & DPR & EGR & DR & Q & LEV & SIZE \\
\hline \multirow[t]{2}{*}{$\mathrm{P} / \mathrm{E}$} & 1.000 & & & & & & \\
\hline & .0958 & & & & & & \\
\hline \multirow[t]{3}{*}{ DPR } & 1.69 & 1.000 & & & & & \\
\hline & 0.091 & & & & & & \\
\hline & $.398^{* *}$ & -.054 & & & & & \\
\hline \multirow[t]{3}{*}{ EGR } & 3.327 & -0.466 & 1.000 & & & & \\
\hline & 0.000 & .641 & & & & & \\
\hline & $-.345^{* *}$ & -.158 & -.172 & & & & \\
\hline \multirow[t]{3}{*}{ DR } & -2.88 & -.494 & -.679 & 1.000 & & & \\
\hline & 0.004 & 0.621 & 0.497 & & & & \\
\hline & .038 & -.047 & .014 & .104 & & & \\
\hline \multirow[t]{3}{*}{ Q } & .940 & -.992 & 1.451 & 1.01 & 1.000 & & \\
\hline & .347 & .321 & .147 & .314 & & & \\
\hline & $-.201^{*}$ & -.234 & $.297^{* *}$ & .069 & .062 & & \\
\hline \multirow[t]{3}{*}{ LEV } & -2.185 & -1.270 & 3.90 & 1.243 & 1.308 & 1.000 & \\
\hline & .029 & .204 & .000 & .214 & .191 & & \\
\hline & $-.037^{*}$ & $.347^{*}$ & .457 & -.021 & $.297^{*}$ & $-.357^{* *}$ & \\
\hline \multirow[t]{2}{*}{ SIZE } & -2.122 & 2.159 & 1.581 & -1.603 & 1.970 & -2.615 & 1.000 \\
\hline & .034 & .031 & .114 & .109 & .049 & .009 & \\
\hline
\end{tabular}

Note. Where P/E is the price earnings ratio as a proxy of the confidence index; DPR is the dividend payout ratio, EGR is the earnings growth ratio; DR is the discount rate; $\mathrm{Q}$ is the Tobin's Q; LEV is the leverage ratio expressed as the dept ratio; SIZE is the firm's size which is the natural logarithm of total asset. First line Pearson correlation coefficient, second line t-value, third line p-value, **, $1 \%$ and $5 \%$ significance level respectively. The critical t-value at $1 \%, 5 \%=2.579 \%$ and $1.96 \%$ respectively.

The main significant positive correlation is found between EGR and confidence index $(\mathrm{P} / \mathrm{E})$, indicating that high earning growth rate Increases the investor's confidence to make investments in Amman Stock Exchange Listed Companies.

\subsection{Regression Analysis}

The Regression analysis is performed to inspect the effect of DPR, EGR, DR, Q, LEV, and SIZE on confidence index of firms listed in Amman Stock Exchange. Nutshell, the variables that were tested in the study can explain $28.6 \%$ of the variation in the confidence index of firms listed in Amman Stock Exchange, as the adjusted $\mathrm{R}^{2}$ in table 3 tells us. Furthermore, the Econometrics model is significant at less than $1 \%(0.000)$ level of significant and has no serial correlation problem as the $\mathrm{D}-\mathrm{W}$ statistic value is 1.832 .

Table 3. Regression analysis

\begin{tabular}{llll}
\hline Variables & $\beta$ & t-statistic & p-value \\
\hline DPR & 3.81 & 6.13 & $.000^{* *}$ \\
EGR & .571 & 2.197 & $.035^{* *}$ \\
DR & .813 & 1.83 & .053 \\
$\mathrm{Q}$ & .519 & 2.83 & $.014^{* *}$ \\
LEV & -2.31 & 1.89 & .058 \\
SIZE & -1.73 & 2.39 & $.027^{* *}$ \\
$\mathrm{R}^{2}$ & .290 & & \\
$\mathrm{R}^{2}$ adj. & .286 & & \\
D-W statistic & 1.832 & & \\
F-statistic & 93.467 & & \\
Sig of F & 0.000 & & \\
\hline
\end{tabular}

Note. Where; DPR is the dividend payout ratio, EGR is the earnings growth ratio; DR is the discount rate; Q is the Tobin's Q; LEV is the leverage ratio expressed as the dept ratio; SIZE is the firm's size which is the natural logarithm of total asset. *** $1 \%$ and $5 \%$ significance level respectively. The critical t-value at $1 \%, 5 \%=2.579 \%$ and $1.96 \%$ respectively. 
Table 3 shows the regression estimates by utilizing pooled data analysis, based on 1380 firm/year observations for firms listed in ASE. Results show that DPR, DR, Q and SIZE significantly explain variations in the confidence index of firms listed in ASE. DPR has the main explanatory power, demonstrating that investors in the ASE are ready to pay higher price for companies that have a high DPR. With other factors constant, the 0.01 increase in the DPR leads to almost a 4 times increase in confidence index (P/E ratio). Results in table 3 also show a positive statically significant impact of earnings growth rate and Tobin's $\mathrm{Q}$ in the confidence index 0.571 $(.035)$ and $0.519(.014)$ respectively.

Size of the firm showed a significant negative association with confidence index -1.73 (.027), implying that investors prefer to invest in small firms rather than big firms. The results of this study support the findings of a study of Banz, R. (1981) and Reinganum, M. (1981) who found an inverse statistically significant relationship between the firm's size and risk-adjusted returns for NYSE firms.

\section{Conclusions}

Understanding the $\mathrm{P} / \mathrm{E}$ ratio and its determinants is of great importance for investors, financial analysts and decision makers, where this ratio is considered an indicator of investor confidence in the company, by understanding the amount of the price at which an investor willing to pay in exchange for one dollar of the firm's profit. Experimental results utilizing pooled data regression analysis indicates that dividend payout ratio, earning growth rate, Tobin's Q and size significantly clarify variations in confidence index of firms listed in ASE, demonstrating that investors' confidence for making investment in ASE is high for small firms with high dividend payout ratio, high earning growth rate and high firm's market value. Thus, to attract investors' business, through raising confidence, firms listed in ASE most pay high dividend, raise their earnings growth and market value of the replacement cost of the firm's assets.

\section{Acknowledgements}

The author is grateful to the Applied Science Private University, Amman, Jordan, for the financial support granted to this research project (Grant No. DRGS-2013-2014-45).

\section{References}

Anderson, K., \& Brooks, C. (2006). Decomposing the Price-Earnings Ratio. Journal of Asset Management, 6(6), 456-469. http://dx.doi.org/10.1057/palgrave.jam.2240195

Andrew, A., \& Zhang, X. Y. (2011). Price-Earnings Ratios: Growth and Discount Rates. Retrieved from https://www0.gsb.columbia.edu/faculty/aang/papers/PEratio.pdf

Banz, R. (1981). The Relationship between Returns and Market Value of Common Stocks. Journal of Financial Economics, 12, 129-156.

Baskin, J. (1989). Dividend Policy and the Volatility of Common Stock. Journal of Portfolio Management, 15(3), 19-25. http://dx.doi.org/10.3905/jpm.1989.409203

Cheng, Ming-Chang, \& Zuwei-Ching, Tzeng. (2011). The Effect of Leverage on Firm Value and how the firm financial quality influence on this effect. World Journal of Management, 3(2), 30-53.

Cho, Y. J. (1994). Determinants of Earnings-Price Ratios: A Reexamination. Review of Financial Economics, 3(2), $105-120$.

Cynthia, A. U. (2012). Company Disclosure in Indonesia: Corporate Governance Practice, Ownership Structure, Competition and Total Assets. Asian Journal of Business and Accounting, 5(1), 75-108.

Dudney, D., Jirasakuldech, B., \& Zorn, T. (2008). Return Predictability and the P/E Ratio: Reading the Entrails. The Journal of Investing, 75-82. http://dx.doi.org/10.3905/joi.2008.710921

Firer, C., Ross, S. A., Westerfield, R. W., \& Jordan, B. D. (2000). Fundamentals of Corporate Finance (3rd ed.). Berkshire: McGraw Hill.

Gill, S. (2003). Price-Earnings Ratio Revisited. Finance India, 17(3), 937-951.

Gordon, M., \& Shapiro, E. (1956). Capital Equipment Analysis: The Required Rate of Profit. Management Science, 3, 102-112. http://dx.doi.org/10.1287/mnsc.3.1.102

Kumar, S., \& Warne, D. P. (2009). Parametric Determinants of Price-Earnings Ratio in Indian Capital Markets. The ICFAI Journal of Applied Finance, 15(9), 63-82.

Reinganum, M. (1981). Misspecification of Capital Asset Pricing: Empirical Anomalies Based on Earnings Yield and Market Values. Journal of Financial Economics, 9, 19-46. 
http://dx.doi.org/10.1016/0304-405X(81)90019-2

Shamsuddin, A., \& Hiller, A. J., (2004). Fundamental determinants of the Australian price-earnings multiple. Pacific-Basin Finance Journal, 12(5), 565-576. http://dx.doi.org/10.1016/j.pacfin.2004.02.001

Ward, M., \& Price, A. (2006). Turning Vision into Value. Preloria: Van Schaik Publishers.

White, C. B. (2000). What P/E will the U.S Stock Market Support? Financial Analysts Journal, 56(6), 30-38. http://dx.doi.org/10.2469/faj.v56.n6.2401

William, B., \& Dale, M. (1978). What Determines Price-Earnings Ratios? Financial Analysts Journal, 34(4), 6576. http://dx.doi.org/10.2469/faj.v34.n4.65

\section{Copyrights}

Copyright for this article is retained by the author(s), with first publication rights granted to the journal.

This is an open-access article distributed under the terms and conditions of the Creative Commons Attribution license (http://creativecommons.org/licenses/by/3.0/). 